DOI: https://doi.org/10.31933/dijms.v2i1 Received: 9 July 2020, Revised: 15 August 2020, Publish: 16 September 2020

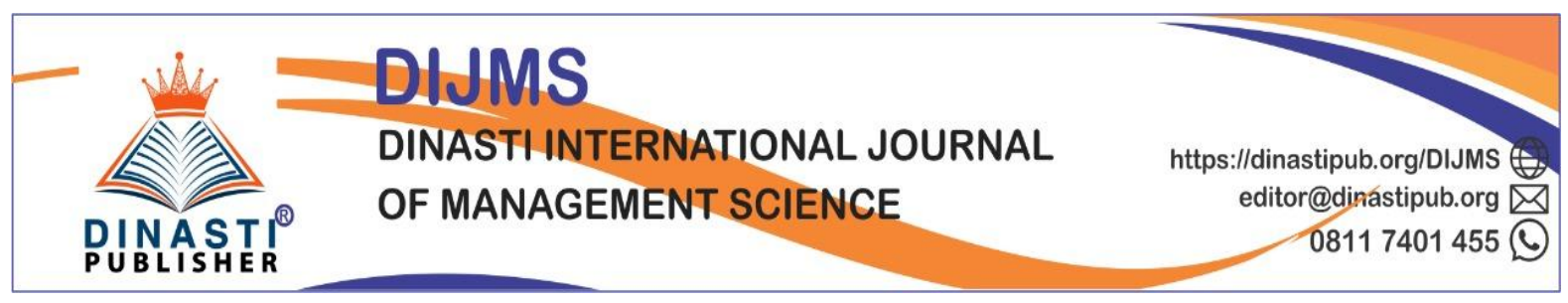

\title{
THE EFFECT OF WORK-FAMILY CONFLICT TOWARDS WORK STRESS ALSO WORK DISCIPLINE AND ITS IMPACT OVER ORGANIZATIONAL COMMITMENT TO FEMALE EMPLOYEES AT YPK MANDIRI MENTENG HOSPITAL IN CENTRAL JAKARTA
}

\author{
Dewi Purwanti ${ }^{1}$, Irfan Noviandy Aulia ${ }^{2}$ \\ 1) Master of Management in Mercu Buana University, Jakarta, Indonesia, purwantidewi95222@ gmail.com \\ ${ }^{2)}$ Lecturer of Postgraduate in Mercu Buana University, Jakarta, Indonesia, irfan.noviandy@ mercubuana.ac.id
}

\section{Corresponding Author: First Author}

\begin{abstract}
This research has purpose to analyze those reaction over work family conflict to organizational commitment with work stress and work discipline as mediating variable. Respondents in this research were all female who works as permanent employees at YPK Mandiri Menteng Hospital as many as 103 employees. The analytical method based on Structural Equation Modeling (SEM) with Partial Least Square (PLS) approach. The findings statement were work stress and work discipline has capable to mediate those partial reaction which occurs on work-family conflict to organizational commitment. Work-family conflict has beneficial and significant reaction over work stress, work stress has negative and significant over organizational commitment, work-family conflict has negative and significant reaction against organizational commitment, work-family conflict has negative and significant impact to work discipline, and work discipline has an positive affects and remarkable against organizational commitment.
\end{abstract}

Keywords: Work-family conflict, work stress, work discipline, organizational commitment.

\section{INTRODUCTION}

Hospital is one of business which provide of health services for publics. A health service organization whose roles of medical and non-medical personnel are resources and its existence is very important. The growth of health workforce in Indonesia from past 8 years as seen in Figure 1 has increased. One of businesses that provide health services in Central Jakarta is YPK Hospital which located on Jalan Gereja Theresia no. 22 Jakarta Pusat. YPK Mandiri Hospital has human resources which dominated by female workers of $80 \%$, while male workers were only $20 \%$ as seen as in Figure 2. Health workers are required to work professionally according to standards set by Hospital, employees at the Hospital YPK Mandiri till lacking in terms of commitment. This could be seen from the number of employees leaving which not proportional to employees recruited (Figure 1) 

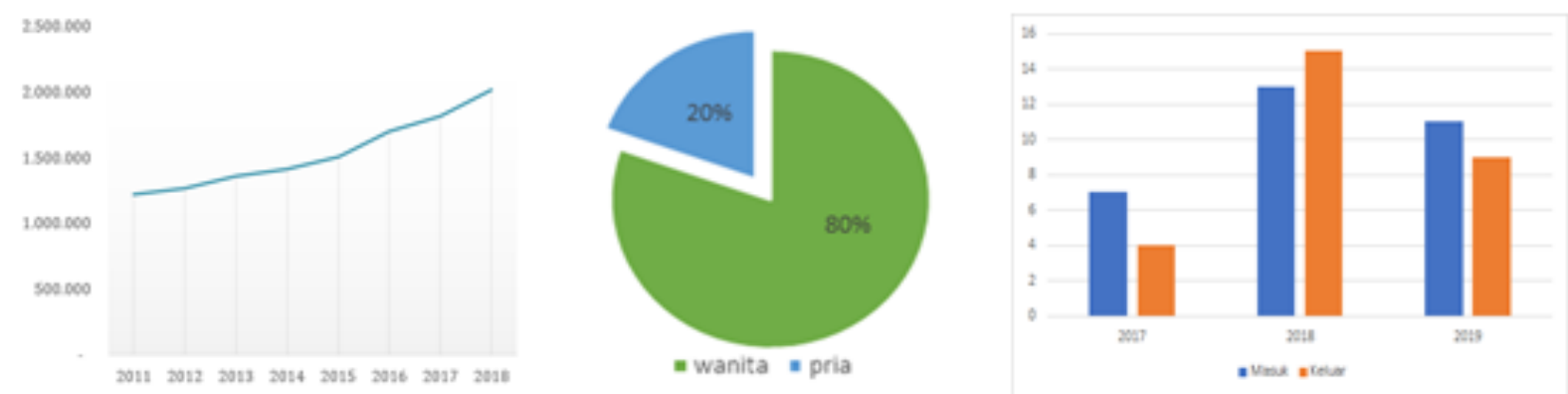

Figure 1. Health Service Workers in 2011-2018, YPK Mandiri Hospital Employees by Gender in October 2019, Number of Employees In and Out of RS.YPK Mandiri

Soure: Statistics Indonesia, KYPYP Mandiri Hospital (2019)

Health workers's commitment would reflected from their work attitude which attentive in carrying out their duties, has a sense of responsibility and very loyal to their institutions. Female health workers has higher commitment on demands because they should be able to put their position as female workers which treat attentive and affectionate towards patients alongside patients' families and also be responsible as housewives (Susijawati, et al. 2017).

Beside that the demands of high commitments, health workers also has demands / workloads which high enough to affect their work stress, this work stress will be a triggerred for serious health problems. In National Institute of Occupational Safety and Health (NIOSH) article was reported about $26 \%$ of workers stated which. work often or very often would felt burned out or depressed by their work.

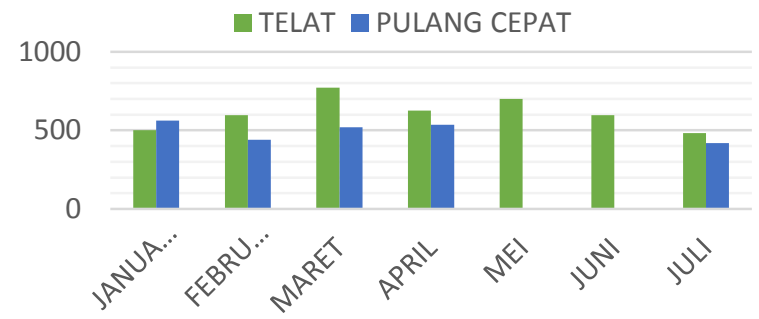

Figure 2. Data on Employee Attendance at YPK Mandiri Hospital Source: List of employees present, 2019

YPK Mandiri Hospital employees were still lacked in discipline in terms of attendance, this could be seen from (Figure 2) There has an employees who arrive not on time (late) or conversely (go home early). Those phenomenon about come and leaving on work hours time will causing problem of health services at YPK Hospital Mandiri which run poorly, because of health sector is vital and involves the lives of many people.

Research which raises human resource issues as described previously that conducted by Choi, Cundiff \& Akhatib (2018) found results that work-family conflict has an strongly rejection over organizational commitment. While recent research conducted by Zain, \& Setiawati (2019), found that work-family conflict has no influence towards organizational commitment, this shows differences in research (research gap).

Based on these phenomena occur and those comparison with prior research regard work-family conflict, work discipline, work stress, organizational commitment, it appears that there has difference in research (reseach gap), therefore the researcher decides to puts 
work stress and work discipline variables as mediating variables both of work-family conflict and organizational commitment. So its very interesting while carry out these research which refers title as "The Effect of of Work-family Conflict towards Work Stress also Work Discipline and its impact on Organizational Commitment to Female Employees at YPK Mandiri Menteng Hospital in Central Jakarta".

\section{LITERATURE REVIEW Work-Family Conflict}

Greenhaus \& Beutell (1985) in Zain \& Setiawan (2019) which defined that workfamily conflict is shape of inter-conflict/conflict between roles, which is contradictory in certain respects. Work-family conflict is role conflict which occurs in individuals who has conflict in middle of work and family. Rabenu, et al. (2017) defined work and family pressure reflects social hopes and self-expectations, which most vulnerable to values, beliefs and self-conceptions due to role of attributes through socialization.

Several research shown that work-family conflict has the most remarkable reaction on desire to leave, burn out and result which expressed as an increase in workplace stress (Rabenu et al., 2017). In addition, An increasing of work-family conflict which felt, the higher of work stress (Amiruddin, A., 2019 ). Long working time and huge workloads is an straight sign of work-family conflict, because those excessive time and effort spent on work results in lack of time and energy that could be used to carry out family activities (Greenhaus \& Beutell, 1985 in Jafar, et. al., 2017). Jafar, et. al. (2017) found that work-family conflict had significant impact to work discipline in negative direction.

The dimensions of work-family conflict according to Greenhaus \& Beutell (1985) in Zain \& Setiawati (2019) used : (a) time-based conflicts; (b) conflict based on tension and (c) conflict based on behavior.

\section{Work Stress}

Robbins and Judge (2013:368) has suggest that stress is a dynamic condition in which an individual faced by opportunities, demands, or resources related to what is desired by that individual and results were seen as uncertain and important. Ivancevich and Matteson's opinion, that quoted by Luthans (2011:279), says work stress has explicate as an flexible feedback (mediated response)whom mediated by individual differences and / or psychological processes as a result of environmental actions, situations or events which cause physical demands and / or excessive psychology towards someone. Purwanti \& Nurhayati (2016:297) explained that stress is condition of distress or suffering that shows coercion, pressure, tension or strong effort, preferably shown in individuals, individual organs or mental strength of a person. Beside that, stress said to be a stimulus which force or impulse to an individual that causes a tension reaction or causes individual physical changes. So it could be said that work stress as an emotional condition of an individual or employee when faced with excessive work demands.

Work stress which adverse reactions experienced by employees in responding to work stressors (Spector, Chen, \& O'Connell, 2000) in Abdelmoteleb, 2018) are considered as 
one of antecedents of organizational commitment or work stress has a negative influence on organizational commitment (Abdelmoteleb, 2018).

There has three dimensions of work stress according to Robbins and Judge (2013:375) namely: (a) physiological symptoms, (b) psychological symptoms, and (c) behavior symptoms.

\section{Work Discipline}

Discipline is someone's awareness and willingness to obey all company regulations and social norms that applied (Hasibuan, 2014:193). Based on Rivai in Amirianzadeh, Hosseini, \& Razmjooei (2018) work discipline is an instrument which castoff by managers to liaise with employees so they would inclined to change their own act as an effort to expand those awareness and prepared to followed all company rules and social norms that applied.

Discipline would growth an employee commitment to company. By trust and accepted it could affect an employee commitment. According to that it could be said that work discipline has an influence towards organizational commitment (Ilahi, Mukzam, \& Prasetya, 2017). Work discipline was created to achieve further organizational goals, Therefore trust and acceptance of employees towards it would bring organization to achieve its goals, work discipline has positive impact over organizational commitment (Amirianzadeh , Hosseini, \& Razmjooei, 2018).

Hasibuan, (2014: 194) said that criteria that used in this research as dimensions from work discipline such as (a) ability goals, (b) level of awareness, (c) adherence to work standards and (d) work ethics.

\section{Organizational Commitment}

Organizational commitment is an individual personal tie in with organization that associated with trust, beliefs and a strong acceptance of goals and values from organization, a strong desire to remain a member of organization and strong willingness to work for organization (Susijawati, et al., 2017) Another opinion was also expressed by Luthans (2011:147) who also defined that organizational commitment as an stance which mirroring those employee's loyalty to their organization and current process and participants could express their concern for organization to survive and wealth. Satwari, et. al. (2016) states that commitment means the desire from employees to retain their membership in organization and willing to go for miles to achieve that organizational goals. From these expert opinion it illustrates that organizational commitment is a desire or willingness from an individual to continue to survive in an organization, as well as willingness to work as much as possible for the benefit of organization whose acceptance of value that in line with goals of organization.

Hidayati (2019) explained that work-family conflicts has experienced continuously will result in pressure on health workers and causing work stress. Beside that those pressure caused by conflict experienced will interfere with health, heavy workload also a factor that causes work stress. Work stress experienced by health workers tends to affect their commitment to the organization.

There has 3 forms of organizational commitment which stated by Allen and Meyer (1991) in Luthans (2011:148), such as (a) affective (b) normative and (c) continuance. 


\section{Conceptual Framework \& Hypothesis}

Research Conceptual Framework model could described as its follows:

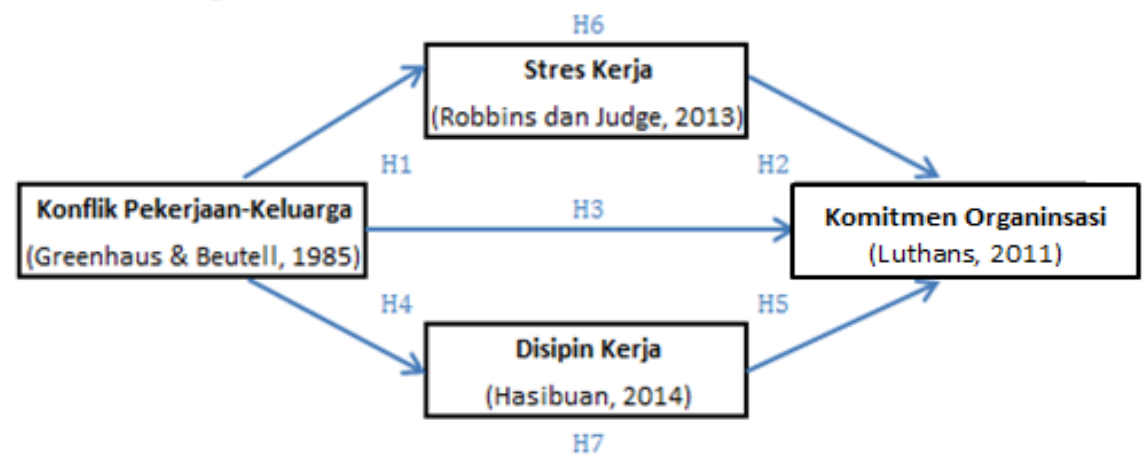

Figure 3. Conceptual Framework

Research Hypothesis:

H1 : Work-family conflict has an remarkable positive influence against work stress.

$\mathrm{H} 2$ : Work stress has an significant positive reaction over organizational commitment.

H3 : Work-family conflict has an turn down reaction over organizational commitment.

H4 : Work-family conflicts negatively affect work discipline.

H5 : Work discipline has positive reaction over organizational commitment.

H6 : Work-family conflict affects against organizational commitment through work stress variable.

H7 : Work-family conflict was influence towards organizational commitment through discipline variable.

\section{RESEARCH METHOD}

This research include in causal research which aims to discover those influence over work-family conflict on work stress and work discipline also its impact to organizational commitment. The population were female permanent employees with married status. The sampling technique used non-probability sampling with saturated sample technique as many as 103 respondents. Data collected techniques by carrying out direct surveys on research object by distributing questionnaires.

The analysis method used elements or Variations Based on Structural Equation Modeling, Partial Least Square is a model of variance based on SEM. PLS is intended for causal-perdictive analysis in situations of high complexity and low theoretical support (Ghozali, 2014). These program used data processing uses Partial Least Square (WrapPLS) version 6.0 .

\section{FINDINGS AND DISCUSSION}

\section{Evaluation of Measurement (outer) Model}

Convergent validity test is a sizing model with reflective indicators gauge based on correlation between item scores/component scores and construct scores calculated by PLS. Discriminant validity is a test of reflective indicators which appeared in cross-loading value between indicator and its construct. 
Table 2. Convergent and Discriminant Validity Test

\begin{tabular}{|c|c|c|c|c|c|c|c|c|c|c|}
\hline \multirow[b]{2}{*}{ Variable } & \multirow[b]{2}{*}{ item } & \multirow{2}{*}{\multicolumn{3}{|c|}{ Information }} & \\
\hline & & & & & & WFC & SK & DK & KO & Type(a \\
\hline \multirow{3}{*}{$\begin{array}{l}\text { Work-family } \\
\text { conflict }\end{array}$} & WFC1 & 0.78 & $<0.001$ & Valid & WFC1 & 0.780 & -0.009 & 0.114 & -0.019 & Reflect \\
\hline & WFC2 & 0.761 & $<0.001$ & Valid & WFC2 & 0.761 & 0.113 & -0.148 & -0.055 & Reflect \\
\hline & WFC3 & 0.876 & $<0.001$ & Valid & WFC3 & 0.876 & -0.090 & 0.027 & 0.065 & Reflect \\
\hline \multirow{3}{*}{ Work stress } & SK1 & 0.741 & $<0.001$ & Valid & SK1 & 0.193 & 0.741 & 0.266 & 0.139 & Reflect \\
\hline & SK2 & 0.707 & $<0.001$ & Valid & SK2 & 0.062 & 0.707 & -0.279 & -0.272 & Reflect \\
\hline & SK3 & 0.771 & $<0.001$ & Valid & SK 3 & -0.243 & 0.771 & 0.000 & 0.116 & Reflect \\
\hline \multirow{4}{*}{$\begin{array}{c}\text { Work } \\
\text { discipline }\end{array}$} & DK1 & 0.813 & $<0.001$ & Valid & DK1 & 0.035 & -0.053 & 0.813 & 0.109 & Reflect \\
\hline & DK2 & 0.740 & $<0.001$ & Valid & DK2 & 0.060 & 0.042 & 0.740 & 0.061 & Reflect \\
\hline & $\mathrm{DK} 3$ & 0.756 & $<0.001$ & Valid & DK 3 & -0.053 & 0.041 & 0.756 & 0.014 & Reflect \\
\hline & DK4 & 0.766 & $<0.001$ & Valid & DK4 & -0.043 & -0.025 & 0.766 & -0.189 & Reflect \\
\hline \multirow{3}{*}{$\begin{array}{l}\text { Organizational } \\
\text { Commitment }\end{array}$} & KO1 & 0.858 & $<0.001$ & Valid & KO1 & 0.092 & 0.003 & 0.025 & 0.858 & Reflect \\
\hline & $\mathrm{KO} 2$ & 0.796 & $<0.001$ & Valid & $\mathrm{KO} 2$ & -0.048 & 0.149 & -0.233 & 0.796 & Reflect \\
\hline & $\mathrm{KO} 3$ & 0.636 & $<0.001$ & Valid & $\mathrm{KO} 3$ & -0.063 & -0.190 & 0.258 & 0.636 & Reflect \\
\hline
\end{tabular}

Based on Table 2. it could be seen that loading factor value of all constructing items shows that each variable is valid or item meets the convergent validity requirement because it has factor loading value above 0.60 and P-Value $<0.001$. The items were declared valid because of high loading factor value to intended construct compared to loading factor to other constructs so it could be said that item already has good discriminant validity criteria.

Reliability testing (Composite reliability) aims to test the reliability of an instrument from research model or sizing internal consistency and its value should above 0.60.

Table 3. Composite Reliability Values

\begin{tabular}{cccc}
\hline WFC & SK & DK & KO \\
0.848 & 0.784 & 0.853 & 0.810 \\
\hline
\end{tabular}

In Table 3. all latent variable values has composite reliability value $\geq 0.7$, it means that those construct has good reliability or questionnaire used as a tool in this research has been reliable or consistent.

\section{Structural Test (Inner) Model}

Those examination of inner models is development of concept and theory based models in order to analyze the relationship between exogenous and endogenous variables.

Table 4. R-Square

\begin{tabular}{cccc}
\hline WFC & SK & DK & KO \\
& 0.194 & 0.074 & 0.234 \\
\hline
\end{tabular}

These model from influence of the latent independent variable (work-family conflict) to work stress gives an R-square value of 0.194. Furthermore, the influence of independent latent variable (work-family conflict) on work discipline gives an R-square value of 0.074. Influence of independent latent variables (work - family conflict, work stress and work discipline) towards organizational commitment gives an R-square value of 0.234.

Goodness of Fit Model, the recommended choice is to try each analysis, which gives the highest goodness of fit then the analysis is chosen. There are 3 criteria for fit indices or model suitability, they are Average path coefficient (APC), Average R-squared (ARS) and Average full collinearity VIF (AFVIF). Model fit indicates thats very important measure because it shows suitability of model with data and shows the quality of research model. 
Table 5. Model Fit and Quality Indices

\begin{tabular}{|c|}
\hline Average path coefficient $(\mathrm{APC})=0.300, \mathrm{P}<0.001$ \\
\hline Average $R$-squared $(\mathrm{ARS})=0.167, \mathrm{P}=0.014$ \\
\hline Average adjusted $R$-squared (AARS) $=0.147, \mathrm{P}=0.023$ \\
\hline Average block VIF (AVIF) $=1.027$, acceptable if $<=5$, ideally $<=3.3$ \\
\hline Average full colline arity VIF $($ AFVIF) $=1.104$, acceptable if $<=5$, ideally $<=3.3$ \\
\hline
\end{tabular}

Based on data analysis by WrapPLS 6.0, P-value APC and ARS < 0.05 and AFVIF $<5$, so that the fit / model fits the available data. The final step of evaluating is structural model (inner model) is to look at the significance value of P-Value to determine the influence between variables based on hypothesis that was built.

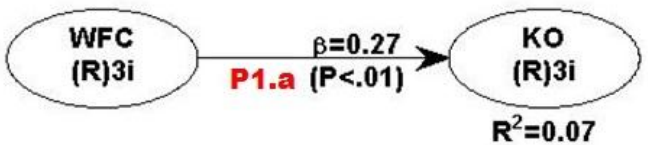

Figure 4. Direct Effect

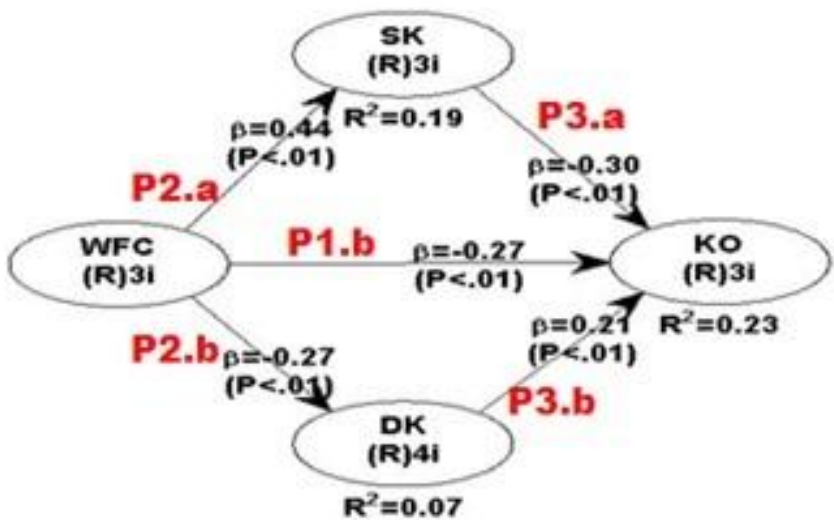

Figure 5. Indirect Effect

Impact of Work - Family Conflict towards Work Stress. According to hypothesis examination in this research, its found that the results of work-family conflict has an positive and significant reaction against work stress. Meaning that the higher of work-family conflict experienced by YPK Mandiri Hospital employees, the higher of work stress she feels. Workfamily conflict has most significant impact towards desire to leave, burn out and results could expressed as an increase in stress at work (Rabenu et al., 2017). These results has similiar research which conducted by Amiruddin, A. (2019) who found that the higher the perceived of work-family conflict, the higher the work stress. In general, respondents feel the conflict caused by the tension which experienced when a role interferes with role of another (strainbased conflict). Conflict caused by tension has two sources, such as work as a source of conflict (Work Related Sources of Conflict) and family as a source of conflict (Family Related Sources of Conflict). In this research, the authors found that one of causes / sources of work-family conflict felt by respondents / employees of YPK Mandiri Hospital was sourced from work (Work Related Sources of Conflict), this was reflected in respondents answered who recognized that "Job demands affect family life. Respondents feel the responsibility of the employee working in a health workforce agency at the YPK Mandiri 
Hospital requires effort or more at work place whereas after employee returns to work it will overwhelm negative emotions that will make her role as a mother / wife (at home) not fulfilled with well,and then this conflict will have an impact on stress at work in form of physical fatigue easily for employee at YPK Mandiri Hospital.

Impact of of Work Stress towards Organizational Commitment. Based on hypothesis examination, these results show that work stress has negative impact over organizational commitment. This means that the more an employee feels work stress could reduce organizational commitment. Work stress which is adverse reactions experienced by employees in responding to work stressors that considered as one of antecedents of organizational commitment (Spector, Chen, \& O'Connell, (2000) in Abdelmoteleb, 2018). The results of hypothesis test are supported by research conducted by Abdelmoteleb, (2018) it was revealed as significant negative impact of work stress to organizational commitment. The stress felt by an employee of YPK Mandiri Hospital which related to its physiology and creates diseases in the body, such as being easily tired. Employees who work in health field services sometimes unwittingly work pressure and emotions make themselves depressed or emotions which uncertain and even depression that causes the body to become easily tired. An employee who feels excessive pressure causing respondents to have less emotional ties to organization (YPK Mandiri Hospital) or it can be said that work stress felt by the employee would decreases their commitment to organization (YPK Mandiri Hospital).

The impact of Work-Family Conflict on Organizational Commitment. Based hypothesis test in this research, it was found that work-family conflict negatively affected organizational commitment. This means that the work-family conflict which felt by workers will cause a decrease in organizational commitment. This result was supported by research which carry out by Chan, \& Ao., (2018) who found that work-family conflicts has negatively influence organizational commitment. Based on role theory, employees who experience higher levels of work-family conflict will have more negative feelings about their work which will reduce their commitment to organization (Chan, \& Ao. 2018). In general, YPK Mandiri Hospital employees feel that conflict caused by difficulty of changing behavior from one role to another. Women's participation in these workforce in this case female employees of YPK Mandiri Hospital are required to undergo two roles at once, such as workers as well as a housewife or conversely. Female employees who are married and have children have heavier roles and responsibilities which certainly not easy. Work-family conflict experienced by an employee of YPK Mandiri Hospital because besides having role in family, these woman also plays a role in her career. Work-family conflicts could explain the conflict between work responsibilities at home or household life. The clash between responsibilities at home or household life makes their commitment to organization decreases evident from continual commitment who really want to (do to) do it (leave the organization). So it could be said that work-family conflict is one of decreasing factors whose influence those organizational commitment in YPK Mandiri Hospital.

The impact of Work-Family Conflict towards Work Discipline. Based on hypothesis test, it was found that work-family conflict has an negative affected to work discipline. It means that the more of employee feels work-family conflict, then the work discipline would be decrease. Long working hours and heavy workloads are a direct sign of work-family 
conflict, because excessive time and effort used to work results in lack of time and energy that can be used to carry out family activities (Greenhaus \& Beutell, 1985 in Jafar et al. 2017). The results of this research were supported by Jafar et al. (2017) who found that workfamily conflict had an significant influences with negative work discipline. Basically, respondents felt the time which they spent working at YPK Mandiri Hospital was one of causes they perceived work-family conflict. The results were in line with futher theory by Korabik et. al. (2008), which states that time pressure is one of the factors which affecting family work conflict. Based on these research mostly YPK Mandiri Hospital employees or as many as 54 respondents (52\%) had more than two children. When a woman devotes too much time and attention to taking care of a child, then affairs at work will become disrupted, so work discipline would be decreases. The number of children can increase a mother's responsibility in terms of her domestic role at home because the main task of a woman in family is capability to take care of family members, and kids is the example. If more time was spent on family then there will be less time for work and would have an impact on carrying out the work. Employees do not carry out the work standards set by YPK Mandiri Hospital such as lack of sense towards responsibility at work place so they wont aware and careful on working with lack of maintain and retain work equipment. Thus these regulations covering work discipline stipulated by YPK Mandiri Hospital which have not been able to be truly implemented.

The impact of Work Discipline against Organizational Commitment. Based on hypothesis examination was found that work discipline has an positive and significant influence on organizational commitment. Meaning that the higher of the work discipline applied by YPK Mandiri Hospital employees, the higher commitment to organization. Work discipline is create to achieve further organizational goals, so with the trust and acceptance of employees in work discipline will bring the organization to achieve its goals Amirianzadeh, Hosseini, \& Razmjooei. (2018) who found that work discipline had a positive reaction over organizational commitment. The results showed discipline affects organizational commitment by 0.215 . Although the grades are not very good, in general the discipline has directed YPK Mandiri Hospital employees to stay in organization. Working in health services has a great responsibility for the health of its patients, there are patients who have to be handled well so the presence of employees at work makes them feel obliged to stay in the organization. This means, employees who have high normative commitment feel that they have to (ought to) survive in organization.

The impact of Work - Family Conflict against Organizational Commitment through Work Stress. Based on hypothesis test, it was found that mediating nature of work stress on relationship between work-family conflict and organizational commitment has partial mediating variable. Based on several hypotheses which have been proven that work-family conflict consist of dimensions of time-base conflict, strain-based conflict and behavior-based conflict. This research directly proves that its influence towards organizational commitment and indirectly proves those influence of organizational commitment through work stress. This finding could compliment or fill the gap in research which conducted by Vickovic \& Morrow (2019) and Zain, \& Setiawati (2019) who found that the results of work-family conflict not having an influence over organizational commitment. It is considered that work-family conflict is a factor that could affect the organizational commitment of a female employee. 
Hidayati (2019) explained that work-family conflicts experienced continuously will result in pressure on health workers and will cause work stress. Beside that these pressure which caused by conflict experienced will interfere with health, heavy workload also a factor that causes work stress. Work stress experienced by health workers tends to affect their commitment to organization. Some supporting research found that work-family conflict has negative and significant influence against organizational commitment with work stress as a mediating variable (Hidayati, 2019). This proves that work stress has capability to act as an intervening variable or able to mediate those influence over work-family conflict against organizational commitment.

The impact of Work-Family Conflict over Organizational Commitment through Work Discipline. According to hypothesis in this research, it was found that mediating nature of work discipline on relationship between work-family conflict and organizational commitment has partial mediating variable. Based on several hypothesis which have been proven that work-family conflict consist of dimensions of time-base conflict, strain-based conflict and behavior-based conflict in this research directly proves its effect on organizational commitment and indirectly proves those influence of organizational commitment through work discipline. This finding can complement or fill the gap in research which conducted by Zain \& Setiawati (2019) who found that results of work-family conflict not having an influence to organizational commitment. It is considered that work-family conflict is a factor that can affect those organizational commitment of a female employee. Work-family conflicts related to work discipline, show that there should be concrete efforts which made to minimize conflicts in family and work. Long working hours and heavy workloads is direct sign of work-family conflict, because excessive time and effort used to work results in a lack of time and energy that can be used to carry out family activities (Greenhaus \& Beutell, 1985). Work-family conflicts that cannot be overcome can be a trigger for a decrease in work discipline. Employees who experience higher levels of work-family conflict will have more negative feelings about their work which will reduce their commitment to organization (Chan, \& Ao. 2018). Research which conducted by Jafar et al. (2017) found that work-family conflict had an influence on work discipline in negative direction or work-family conflict had negative influence over work discipline. Furthermore, research conducted by Amirianzadeh, Hosseini, and Razmjooei (2018) found that work discipline has a significant reaction over organizational commitment.

\section{CONCLUSION AND SUGGESTION}

According to results and discussion in previous chapters, these following conclusions could be drawn as in belows: a) Work-family conflict has positive and strongly impact over work stress at YPK Mandiri Hospital Jakarta; b) Work stress has contradict influence over organizational commitment at YPK Mandiri Hospital employees Jakarta; c) Work-family conflict has negate and crucial impact to organizational commitment at YPK Mandiri Hospital employees Jakarta; d) Work-family conflict has minus and remarkable influence on employee work discipline at YPK Mandiri Hospital Jakarta; e) Work discipline has decisive and strong reaction towards organizational commitment at YPK Mandiri Hospital employees Jakarta; f) work stress has partially effect towards the connection both work-family conflict also organizational commitment at YPK Mandiri 
Hospital employees in Jakarta; g) Work discipline has partially influence between workfamily conflict and organizational commitment at YPK Mandiri Hospital Jakarta employees.

General advice for medical and non-medical workers there should be the leader of YPK Mandiri Hospital who would implement work-life balance (such as: provide fewer night shifts for female employees, especially those are married, in medical division which requires work schedule of 3 shifts); recruiting more male employees so there is no imbalance between female employees and male employees; besides that YPK Mandiri Hospital should give an reward employees to employee who have worked for more than 5 years, it is also expected to increase employees' emotional attachment to Hospital.

\section{REFERENCE}

Abdelmoteleb, S. A. (2018). A New Look at the Relationship Between Job Stress and Organizational Commitment: a Three-Wave Longitudinal Study. Journal of Business and Psychology. doi:10.1007/s10869-018-9543-z

Amiruddin, A. (2019). Mediating effect of work stress on the influence of time pressure, work-family conflict and role ambiguity on audit quality reduction behavior. International Journal of Law and Management, 00-00.

Amirianzadeh, M., Hosseini, N., Razmjooei, Parvin. (2018). "Effect of social discipline and work consciousness on nurses' productivity by considering mediating role of organizational commitment in public hospitals of Tehran University of Medical Sciences". Revista Publicando, 5 No 16. (1). 2018, 165-177. ISSN 13909304

Chan, S. H. J., \& Ao, C. T. D. (2018). The Mediating Effects of Job Satisfaction and Organizational Commitment on Turnover Intention, in the Relationships Between Pay Satisfaction and Work-Family Conflict of Casino Employees. Journal of Quality Assurance in Hospitality \& Tourism, 1-24. doi:10.1080/1528008x.2018.1512937.

Choi, S. B., Cundiff, N., Kim, K., \& Akhatib, S. N. (2018). The Effect of Work-Family Conflict and Job Insecurity on Innovative Behaviour of Korean Workers: The Mediating Role of Organisational Commitment and Job Satisfaction. International Journal of Innovation Management, 22(01), 1850003.

Ghozali, Imam. (2014). Structural Equation Modeling, Metode Alternatif dengan Partial Least Square (PLS). Edisi 4.Semarang: Badan Penerbit Universitas Diponegoro

Hasibuan, Malayu. (2014). Manajemen Sumber Daya Manusia. Jakarta: Bumi Aksara

Ilahi, D. K., Mukzam, M. D., \& Prasetya, A. (2017), "Pengaruh Kepuasan Kerja Terhadap Disiplin Kerja dan Komitmen Organisasional (Studi pada Karyawan PT. PLN (Persero) Distribusi Jawa Timur Area Malang)", Jurnal Administrasi Bisnis $(J A B) \mid$ Vol. 44 No.1

Jafar, Faozi \& Dwiyanti, Retno \& Rahardjo, Pambudi. (2017). Work-Family Conflict dengan Disiplin Kerja Anggota Polri Distrik Wanadadi Polres Banjarnegara. Psycho Idea. 15. 1. 10.30595/psychoidea.v15i1.2233 
Korabik, K., McElwain, A., \& Chappell, D. B. (2008). Integrating gender-related issues into research on work and family. In Handbook of work-family integration (pp. 215- 232). Academic Press.

Luthans, Fred. (2011). Organizational Behavior: an Evidence-Based Approach. Edisi 12. McGraw-Hill. New York.

Purwanti, D., \& Nurhayati, M. (2016). Pengaruh Iklim Organisasi dan Tipe Kepribadian

Robbins, Stephen P.and Judge, Timothy A. (2013). Organizational Behavior, New Jersey; Pearson Education Inc.

Satwari, Musadieq, M, Afrianty. (2016). Pengaruh Komitmen Organisasional Terhadap Turnover Intention. Jurnal Administrasi Bisnis, Vol 40.

Susijawati, N., Maryam, S., \& Sulistiowati, L. H. (2017). Konflik Peran Ganda, Disiplin dan Komitmen Organisasi Terhadap Kinerja Perawat pada RSUD Gunung Jati Kota Cirebon. LOGIKA Jurnal Ilmiah Lemlit Unswagati Cirebon, 19(1), 69-72.

Zain, A. N. D., \& Setiawati, T. (2019). Influence of Work Family Conflict and Job Satisfaction on Medical Employee Performance through Organizational Commitment. Review of Integrative Business and Economics Research, 8(1),1-19. 